\title{
Evaluation of Soil Fertility Gradient Experiment on the Basis of Crop Yield, Nutrient uptake and Soil Fertility
}

\author{
Vijay Kant Singh ${ }^{1 *}$, Poonam Gautam ${ }^{1}$, Sobaran Singh ${ }^{1}$, \\ Navneet Pareek ${ }^{1}$ and V. P. Singh ${ }^{2}$ \\ ${ }^{1}$ Department of Soil Science, ${ }^{2}$ Department of Agronomy, G.B.P.U.A.\&T, \\ Pantnagar-263145, Uttarakhand, India \\ *Corresponding author
}

Keywords

Soil fertility gradient, wheat, STCR, nitrogen, phosphorus, potassium, nutrient uptake, yield.

Article Info

Accepted:

18 January 2020

Available Online:

10 February 2020

\section{A B S T R A C T}

Field experiment was carried out on wheat crop at N.E. Borlaug Crop Research Centre, G.B.U.A.\&T, Pantnagar during Rabi 2016-17 to evaluate the impact of soil fertility gradient on crop yield, nutrient uptake and soil fertility. The experiment field was divided in three equal strips and three graded levels of fertilizer $\mathrm{N}, \mathrm{P}_{2} \mathrm{O}_{5}$ and $\mathrm{K}_{2} \mathrm{O}$ were applied as $\mathrm{N}_{0} \mathrm{P}_{0} \mathrm{~K}_{0}, \mathrm{~N}_{100} \mathrm{P}_{100} \mathrm{~K}_{100}$ and $\mathrm{N}_{200} \mathrm{P}_{200} \mathrm{~K}_{200}$ in strip I, strip II and strip III, respectively. N:P:K mixture, urea and muriate of potash were used as source of nutrients. Exhaust crop wheat was grown by following recommended agronomic practices and harvested at maturity. Straw and grain samples were collected from each strip and analyzed for nitrogen, phosphorus and potassium content and total nutrient uptake was worked out. Grain and straw yield were also recorded after harvesting the crop. Soil samples were taken before and after the harvest of the crop from the surface layer and analyzed for available $\mathrm{N}$, available $\mathrm{P}$ and available $\mathrm{K}$. Wide variation in wheat yield, nutrient uptake and soil fertility was recorded between strips which confirmed the impact of graded levels of fertilizer application on these parameters and establishment of soil fertility gradient.

\section{Introduction}

Nutrient management is one of the important aspects of maintaining soil health and crop productivity. Application of nutrients, management practices in diverse ecologies and production systems are critical to enhance farm productivity, resource efficiency, food grain production and reducing environmental risks. Fertilizer is one of the expensive inputs in crop husbandry therefore the use of right dose of fertilizer is the fundamental need for farm profitability and environmental protection (Kimetu et al., 2004).

It constitutes an essential component for crop production and the requisite amount of fertilizer application is considered as a key to the plentiful crop production (Tariq et al., 
2007). Over the past few decades, fertilizer consumption in India has increased appreciably. But, it is important to note that Indian agriculture is running at 'net negative nutrient balance' of staggering 8-10 million tonnes per year (Tandon, 2004) which is set to reach around 15 million tonnes by 2025 . Application of chemical fertilizers by the farmer without information on present soil fertility status and nutrient requirement by the specific crop affects soil and crop adversely (Ray et al., 2000).

Intensive cropping and imbalanced fertilizer applications are major reasons for exhaustion of macronutrients like nitrogen, phosphorus and potassium. Soil test crop response (STCR) approach takes into account, the amount of the nutrient removed by the crop, initial level of soil fertility, the efficiency of nutrient uptake from the soil and fertilizers therefore, fertilizer prescription based on this approach is designed to maintain soil fertility and reduce fluctuations in yield.

Soil fertility gradient approach aims at eliminating the influence of other factors affecting yield like crop, climate and management by choosing one field over which elaborate treatments are superimposed to obtain crop responses for correlating with soil test values which are artificially created by differential fertilizer treatments before conducting the regular experiment and provides a scientific basis for balanced fertilization between applied and soil available forms of nutrients.

Wheat (Triticum aestivum L.) one of the important staple food grain crops next to rice both in area and production. Current wheat production in country is around 99 million tonnes from an area of 30.8 million hectares with productivity of 3.2 tonnes $\mathrm{ha}^{-1}$ (ASG, 2018). It contributes about 36 percent of country's total food grain production (GOI,
2016-17). Wheat occupies about 3.5 lakh hectares in Uttarakhand with 8.8 lakh metric tonnes production and $25.83 \quad \mathrm{q} \quad \mathrm{ha}^{-1}$ productivity (ASG, 2018). Wheat is one of the nutrient exhaustive crops which are helpful in creation of artificial soil fertility gradient due to their high nutrient responsive nature.

Exhaust crop is grown so that the fertilizers undergo transformations in the soil with plant and microbial activity. Nutrients like nitrogen, phosphorus and potassium play role in overall plant growth and development of the crop, hence required in large amount. The objective of this study was to evaluate the impact of soil fertility gradient on yield, nutrient uptake and soil fertility.

\section{Materials and Methods}

The methodology adopted in this investigation was to get as large variation as possible in the soil fertility levels in one and the same field so that the real relationship between the yield and the level of soil fertility could be evaluated without interference from other factors affecting yield (Ramamoorthy et al., 1967). Operational range of variation in soil fertility was created artificially to generate data covering an appropriate range of values for each controllable variable (fertilizer dose) at different levels of an uncontrollable variable (soil fertility) which could not be expected at one place normally.

Hence, in order to create soil fertility variation in the same field and to evaluate the impact of soil fertility gradient experiment on crop yield, nutrient uptake and soil fertility a field experiment was conducted during rabi 2016-17 with exhaust crop wheat (var. UP 2526) at Norman E. Borlaug Crop Research Centre, G.B. Pant University of Agriculture and Technology, Pantnagar $\left(29^{\circ} \mathrm{N}\right.$ latitude, $79^{\circ} 29^{\prime}$ E longitude and $243.84 \mathrm{~m}$ above 
MSL), District U.S. Nagar, Uttarakhand. Experimental field was divided into three equal strips $(75.0 \mathrm{~m} \times 7.5 \mathrm{~m})$ and initial soil sample was taken before the application of fertilizers. Graded doses of fertilizer nutrients $\mathrm{N}, \mathrm{P}_{2} \mathrm{O}_{5}$ and $\mathrm{K}_{2} \mathrm{O}$ were applied in strip I $\left(\mathrm{N}_{0} \mathrm{P}_{0} \mathrm{~K}_{0}\right)$, strip II $\left(\mathrm{N}_{100} \mathrm{P}_{100} \mathrm{~K}_{100}\right)$, and strip III $\left(\mathrm{N}_{200} \mathrm{P}_{200} \mathrm{~K}_{200}\right)$ (Table1). Nutrient sources used were $\mathrm{N}$ : $\mathrm{P}$ : $\mathrm{K}$ mixture, urea and MOP fertilizers. Exhaust crop wheat was grown by following recommended agronomic practices and crop was harvested at maturity and a sample sized of $4 \mathrm{~m}^{2}(2 \mathrm{~m} \times 2 \mathrm{~m})$ area from randomly selected three spots from each strip were taken.

Harvested crop was left in the field for sun drying; thereafter average biological yield $(\mathrm{kg}$ $\mathrm{m}^{-2}$ ) was recorded. After threshing of produce strip wise average grain yield $\left(\mathrm{kg} \mathrm{m}^{-2}\right)$ was recorded and deducted from the average biological yield to get average straw yield (kg $\mathrm{m}^{-2}$ ) and reported as quintal per hectare. Collected straw and grain samples from each strip were analyzed for total nitrogen, phosphorus and potassium content (Jackson, 1967) and total nutrient uptake by the crop was worked out.

Soil sample was collected from the surface layer before the sowing of the exhaust crop, air dried in shade, processed and used in chemical analysis for EC (Bower and Wilcox .,1965), pH (Jackson, 1958), Soil organic carbon( Walkley and Black, 1934), available nitrogen by Alkaline $\mathrm{KMnO}_{4}$ method ( Subbiah and Asija, 1956), available phosphorus by Olsen's method (Olsen et al., 1954) and available potassium by Neutral normal ammonium acetate method (Hanway and Hiedal, 1952).

Twenty four soil samples were also collected from each strip after the harvest of the exhaust crop and analyzed for the determination of available nitrogen, available phosphorus and available potassium by adopting the similar procedures as outlined above.

\section{Results and Discussion}

The soil of the experimental field was silty clay loam in texture, with $7.33 \mathrm{pH}, 0.407 \mathrm{dS}$ $\mathrm{m}^{-1}$ electrical conductivity and 0.571 percent soil organic carbon content. Initial soil test value of available nitrogen, available phosphorus and available potassium was $150.53 \mathrm{~kg} \mathrm{~N} \mathrm{ha}^{-1}, 15.64 \mathrm{~kg} \mathrm{P} \mathrm{ha}^{-1}$ and 141.12 $\mathrm{kg} \mathrm{K} \mathrm{ha}^{-1}$, respectively.

\section{Yield and nutrient uptake by exhaust crop wheat}

Results showed that application of graded level of nutrients $\left(\mathrm{N}, \mathrm{P}_{2} \mathrm{O}_{5}\right.$ and $\left.\mathrm{K}_{2} \mathrm{O}\right)$ on yield and uptake of exhaust crop wheat was prominent (Table 2). The results of soil fertility gradient experiment revealed that the highest grain yield of exhaust crop was obtained in strip III (46.67 $\mathrm{q} \mathrm{ha}^{-1}$ ) followed by strip II (38.33 q ha $\left.{ }^{-1}\right)$ and the least in strip I (16.67 q ha $\left.{ }^{-1}\right)$.

Similarly straw yield was 29.17, 65.83 and $78.33 \mathrm{q} \mathrm{ha}^{-1}$ in strip I, II and III, respectively. In strip III, where the fertilizer $\mathrm{N}, \mathrm{P}_{2} \mathrm{O}_{5}$ and $\mathrm{K}_{2} \mathrm{O}$ applied were twice as that of strip II, the grain yield recorded an increase of 179.96 and 21.76 percent over strip I and II respectively. Whereas, straw yield recorded an increase of 168.53 and 18.99 percent over strip I and II respectively. It might be due to that graded levels of nutrient application enhanced nutrient uptake and growth parameters. Verma et al., (2014) also found that application of graded level of fertilizers to gradient crop of rice recorded higher grain and straw yield.

Total nitrogen uptake by the crop was recorded in order of $32.96 \mathrm{~kg} \mathrm{ha}^{-1}$ in strip I, 
$85.17 \mathrm{~kg} \mathrm{ha}^{-1}$ in strip II and $117.95 \mathrm{~kg} \mathrm{ha}^{-1}$ in strip III. Percent increase in nitrogen uptake in strip III over strip II and strip I was 38.49 and 257.86, respectively and that of strip II over strip I was 158.40. Total phosphorus uptake by crop was recorded maximum 21.41 $\mathrm{kg} \mathrm{ha}{ }^{-1}$ under strip III followed by $15.08 \mathrm{~kg}$ $\mathrm{ha}^{-1}$ in strip II and minimum $4.41 \mathrm{~kg} \mathrm{ha}^{-1}$ in strip I. Total uptake of potassium by crop was maximum $91.93 \mathrm{~kg} \mathrm{ha}^{-1}$ in strip III followed by $70.05 \mathrm{~kg} \mathrm{ha}^{-1}$ in strip II and the least 28.13 $\mathrm{kg} \mathrm{ha}^{-1}$ in strip I.

The percent increase in uptake of phosphorus and potassium in strip III over strip II and strip I was 41.98 and $385.49,31.23$ and 226.80 , respectively. Increase in uptake of phosphorus and potassium by the crop in strip II over strip I was 241.95 and 149.02 percent, respectively (Table 2). The increase in phosphorus uptake was due to higher levels of phosphorus application which would have led to higher root proliferation of the crop (Verma et al., 2014).

\section{Soil fertility status after the harvest of exhaust crop}

Average soil test values after the harvest of exhaust crop showed conspicuous effect of varied levels of nutrient treatments on soil properties (Table 3). Soil available nitrogen, phosphorus and potassium content prominently increased from strip I to strip III. Average soil test value of available nitrogen (Alkaline- $\mathrm{KMnO}_{4}-\mathrm{N}$ ) was $165.16 \mathrm{~kg} \mathrm{~N} \mathrm{ha}^{-1}$ in strip I, $169.34 \mathrm{~kg} \mathrm{~N} \mathrm{ha}^{-1}$ in strip II and 171.96 $\mathrm{kg} \mathrm{N} \mathrm{ha}{ }^{-1}$ in strip III. Mean value of available soil phosphorus was $16.87 \mathrm{~kg} \mathrm{P} \mathrm{ha}^{-1}$ in strip I, $17.67 \mathrm{~kg} \mathrm{P} \mathrm{ha}^{-1}$ in strip II and $18.91 \mathrm{~kg} \mathrm{P} \mathrm{ha}$ ${ }^{1}$ in strip III. Average soil test value of available potassium was $144.34,154.33$ and $156.52 \mathrm{~kg} \mathrm{~K} \mathrm{ha}^{-1}$ in strip I, II and III, respectively. Soil test values of alkaline $\mathrm{KMnO}_{4}-\mathrm{N}$, Olsen's-P and $\mathrm{NH}_{4} \mathrm{OAc}-\mathrm{K}$ was highest in strip III followed by strip II and the least in strip I. Marked increase in fertility gradient build up with respect to available $\mathrm{N}$, $\mathrm{P}$ and $\mathrm{K}$ was noted from strip I to strip III (strip $\mathrm{I}<$ strip II $<$ strip III). Highest soil test values of available nutrients in strip III might be due to very high nutrient application with super-optimal doses of nutrients in strip III than no application of nutrients in strip I. Such type of marked fertility gradient build up by preliminary fertility gradient experiment have been also reported by Udayakumar and Santhi (2017).

It is evident from the above data that wide variability existed in soil test values of available nutrients. In quantitative terms, soil fertility gradient build up was observed 4.12, 12.09 and 8.44 per cent for alkaline $\mathrm{KMnO}_{4}$ $\mathrm{N}$, Olsen's-P and $\mathrm{NH}_{4} \mathrm{OAc}-\mathrm{K}$ in strip III over strip I, respectively. While it was $2.53,4.74$ and 6.92 per cent for alkaline $\mathrm{KMnO}_{4}-\mathrm{N}$, Olsen's-P and $\mathrm{NH}_{4} \mathrm{OAc}-\mathrm{K}$ in strip II over strip I, respectively. Gradient build up for alkaline $\mathrm{KMnO}_{4}-\mathrm{N}$, Olsen's-P and $\mathrm{NH}_{4} \mathrm{OAc}$ $\mathrm{K}$ was $1.55,7.02$ and 1.42 per cent in strip III over strip II, respectively. This variation in the strips with regards to soil fertility was prerequisite for calculating the basic parameters and fertilizer prescription equations for calibrating fertilizer doses for desired target yield of different crops. The results corroborate with the findings of Ahmed et al., (2015).

Yield and uptake data indicated that fertility gradient has been created since crop yield and total nutrient uptake by the exhaust crop followed the same trend as of the applied fertilizer nutrients, i.e. strip III > strip II > strip I. It may be due to the application of graded levels of $\mathrm{N}, \mathrm{P}$ and $\mathrm{K}$ in strips which influenced the grain yield and nutrient availability and nutrient uptake by the crop. Similar observations were also reported by Srinivasan and Angayarkanni (2008) and Singh et al., (2015) with rice. 
Table.1 Nutrient doses applied in soil fertility gradient experiment with wheat crop

\begin{tabular}{|c|c|c|c|c|}
\hline Strip & \multirow{2}{*}{ Symbol } & \multicolumn{3}{|c|}{ Nutrient dose $\left(\mathbf{k g ~ h a}^{-\mathbf{1}}\right)$} \\
\cline { 3 - 5 } & & $\mathbf{N}$ & $\mathbf{P}_{\mathbf{2}} \mathbf{O}_{\mathbf{5}}$ & $\mathbf{K}_{\mathbf{2}} \mathbf{O}$ \\
\hline I & $\mathbf{N}_{\mathbf{0}} \mathbf{P}_{\mathbf{0}} \mathbf{K}_{\mathbf{0}}$ & 0 & 0 & 0 \\
\hline II & $\mathbf{N}_{\mathbf{1}} \mathbf{P}_{\mathbf{1}} \mathbf{K}_{\mathbf{1}}$ & 100 & 100 & 100 \\
\hline III & $\mathbf{N}_{\mathbf{2}} \mathbf{P}_{\mathbf{2}} \mathbf{K}_{\mathbf{2}}$ & 200 & 200 & 200 \\
\hline
\end{tabular}

Table.2 Effect of graded levels of nutrients on grain yield, straw yield and nutrient uptake by exhaust crop wheat in soil fertility gradient experiment

\begin{tabular}{|c|c|c|c|c|c|}
\hline \multirow[t]{2}{*}{ Strip } & Grain yield & Straw yield & \multicolumn{3}{|c|}{$\begin{array}{c}\text { Total nutrient uptake } \\
\left(\mathrm{kg} \mathrm{ha}^{-1}\right)\end{array}$} \\
\hline & \multicolumn{2}{|c|}{$\left(\mathrm{q} \mathrm{ha}^{-1}\right)$} & $\mathbf{N}$ & $\mathbf{P}$ & $\mathbf{K}$ \\
\hline I & 16.67 & 29.17 & 32.96 & 4.41 & 28.13 \\
\hline II & 38.33 & 65.83 & 85.17 & 15.08 & 70.05 \\
\hline III & 46.67 & 78.33 & 117.95 & 21.41 & 91.93 \\
\hline
\end{tabular}

Table.3 Effect of graded levels of nutrients on soil fertility status after the harvest of exhaust crop in soil fertility gradient experiment

\begin{tabular}{|c|c|c|c|c|}
\hline Strip & \multirow{2}{*}{ Symbol } & \multicolumn{3}{|c|}{ Nutrient $\left(\mathbf{k g ~ h a}^{-\mathbf{1}}\right)$} \\
\cline { 3 - 5 } & & $\begin{array}{c}\text { Available } \\
\text { nitrogen }\end{array}$ & Available phosphorus & Available potassium \\
\hline I & $\mathbf{N}_{\mathbf{0}} \mathbf{P}_{\mathbf{0}} \mathbf{K}_{\mathbf{0}}$ & 165.16 & 16.87 & 144.34 \\
\hline II & $\mathbf{N}_{\mathbf{1}} \mathbf{P}_{\mathbf{1}} \mathbf{K}_{\mathbf{1}}$ & 169.34 & 17.67 & 154.33 \\
\hline III & $\mathbf{N}_{\mathbf{2}} \mathbf{P}_{\mathbf{2}} \mathbf{K}_{\mathbf{2}}$ & 171.96 & 18.91 & 156.52 \\
\hline
\end{tabular}

On the basis of soil fertility gradient crop experiment, it can be concluded that an application of graded levels of nutrients (NPK) application resulted in marked variation in wheat yield, nutrient uptake and soil fertility between strips which confirmed the prominent impact of graded level of fertilizer nutrients on crop yield, nutrient uptake and soil fertility.

\section{References}

Ahmed, S., Basumatary, A., Das, K.N. and Medhi, B.K. (2015). Targeted yield based fertilizer prescriptions for autumn rice (Oryza sativa L.) in Inceptisols of
Assam, India. Indian J. Agric. Res., 49 (5): 437-441.

ASG, (2018). Agricultural Statistics at a Glance. Directorate of Economics and Statistics, Department of Agriculture, Cooperation \& Farmers Welfare, Ministry of Agriculture \& Farmers Welfare, Government of India.

Bower, C.A. and Wilcox, L.A. (1965). Methods of soil analysis. Part-1, chemical and microbiological properties.62: 933-951.

GOI. (2016-17). Agriculture Statistics at a Glance, Ministry of Agriculture and Farmer Welfare Department of Agriculture, cooperation and farmer's 
Welfare Directorate of Economics and statistics, pp 370- 380.

Hanway, J.J. and Hiedal, H. (1952). Soil analysis method used in Iowa State Soil Testing Laboratory, Iowa Agric. Ameri. Soc. Agron., 57:1025-1027.

Jackson, M. L. (1958). Soil chemical analysis. Prentice Hall. Inc. Englehood cliffs, N.J., USA.

Jackson, M. L. (1967). Soil chemical analysis. Prentice Hall of India (P) Ltd., New Delhi.

Kimetu, M., Mugendi, D.N., Palm, C.A., Mutuo, P.K., Gachengo, C.N. and Nandwa, S. (2004). African network on soil biology and fertility. 207-224.

Olsen, S,R., Cole, C.V., Watandbe, F.S. and Dean, L.A. (1954). Estimation of available Phosphorus in soil by extraction with Sodium Bicarbonate. $J$. Chem. Inf. Model. 53 (9):1689-1699.

Ramamoorthy, B., Narasimham, R.L. and Dinesh, R.S. (1967). Fertilizer application for specific yield target of sonara-64 wheat. Ind. Farming, 17: 4345.

Ray, P.K., Jana, A.K., Maitra, D.N., Saha, M.N., Chaudhury, J., Saha, S. and Saha, A.R. (2000). Fertilizer prescriptions on soil test basis for jute, rice and wheat in Typic Ustochrept. J. Ind. Soc. Soil Sci., 48: 79-84.

Singh, Y.V., Shiva, A.M. and Dey, P. (2015). Soil test crop response based gradient experiment on rice (Oryza sativa L.) to
NPK fertilizers in the alluvial soil of the Indo-Gangetic plains. Crop Res., 50 (1, $2 \&$ 3):9-11.

Srinivasan, S. and Angayarkanni, A. (2008). Effect of INM on yield and nutrient uptake by rice in STCR experiment. Agric. Sci. Digest., 28(2): 130-132.

Subbiah, A.V. and Asija, G.L. (1956). A rapid procedure for assessment of available nitrogen in rice plots, Current Sci., 31: 196-200.

Tandon, H.L.S. (2004). Fertilizers in Indian agriculture from $20^{\text {th }}$ to $21^{\text {st }}$ century. FDCO, New Delhi.

Tariq, J.M.T., Arif, M., Akbar, H. and Ali, S. (2007). Response of wheat to source, type and time of $\mathrm{N}$ application. Sarhad J. Agric., 23 (4): 871-879.

Udayakumar, S. and Santhi, R. (2017). Impact of Artificial Soil Fertility Gradient Strategy on Soil Fertility, Nutrient Uptake and Fodder Yield of Sorghum. Int. J. Curr. Microbiol. App. Sci., 6(3): 938-944.

Verma, M., Singh, Y.V., Ajay Babu, Verma, S., Meena, R. and Sahi, S.K. (2014). Soil test crop response based gradient experiment on rice (Oryza sativa L.) to fertilisers in the alluvial soil. Ind. J. Agri. \& Allied Sci., 1 (4): 51-53.

Walkley, A. and Black, C.A. (1934). An examination of degtjareff method for determining soil organic carbon and a proved modification of chromic acid titration method. Soil Sci., 37: 29-38.

\section{How to cite this article:}

Vijay Kant Singh, Poonam Gautam, Sobaran Singh, Navneet Pareek and Singh. V. P. 2020. Evaluation of Soil Fertility Gradient Experiment on the Basis of Crop Yield, Nutrient uptake and Soil Fertility. Int.J.Curr.Microbiol.App.Sci. 9(02): 2435-2440. doi: https://doi.org/10.20546/ijcmas.2020.902.278 